\title{
ヘルシンキ都心部にみる近・現代建築コンバージョン 部位別保存手法の運用事例研究 \\ OPERATIVE CASE STUDY OF THE PRESERVATION TECHNIQUE ACCORDING TO THE PART OF THE MODERN ARCHITECTURE CONVERSION IN THE HELSINKI INNER CITY
}

\author{
田中 雅 美*
}

Masami TANAKA

\begin{abstract}
1. Through the investigation into operative examples as for the preservation technique according to the part that the Helsinki City Planning Department applied, it was confirmed that a local detailed plan is going to be made while fixing its eyes on a reevaluation and the conversion purpose of the existing building as a sheet of plastic from an initial stage in consideration for a local detailed plan to prescribe preservation requirements.
\end{abstract}

2. This operative technique brings the flexibility and diversity that met an individual building in a preservation requirements and it is thought that it functions in raising originality and quality of the conversion architecture.

\section{Keywords : preservation according to the part, flexibility and diversity of preservation requirements, originality of the conversion architecture \\ 部位別保存，保存要件の柔軟性と多様性，コンバージョン建築の創造性}

\section{1. 研究背景}

コンバージョン 1)によって既存環境を改善するという手法は、欧 米諸外国においても日本においても、実現可能な有効な建築手法と して認知されてきた。なかでも現在の生活の身近にある優れた近・ 現代建築を保存活用し私たちの生活環境を豊かにしていこうという 思潮が顕在化している。さらに保存と改修を同時に行うコンバージ ヨン設計では新築設計では構築できない時間軸を取込んだ新たな建 築創造の可能性も期待される ${ }^{2,3,4,5)}$ 。コンバージョン建築を取りま く日本の今日的状況の中で、海外事例を基礎資料とした研究が進ん でいる。積極的にコンバージョン建築へ導く行政手法や既存建築の 保存を決定する法的な枠組みを持つ欧米諸外国の都市計画手法、さ らにコンバージョンをデザイン手法の観点から調査した一連の海外 事例研究 ${ }^{6)}$ などである。このような既往研究の広がりの中で、本稿 はヘルシンキ都心部のコンバージョン事例を基礎資料として既存建 築の保存部位と保存目的を決定する検討プロセスについて論考する ものである。

近・現代建築のコンバージョンでは他の様式建築とは異なる計画 上の考慮点が指摘される。近・現代建築は用途に対し空間ヴォリュ 一ムが必要条件的思考で設計されていることが多いため、空間が限 定的であることが多い。さらに空間をつくる構法や技術が建築デザ インと緊密に関連しているために、用途変更や耐久性、環境負荷の 軽減など今日的な課題に対し柔軟性に乏しい傾向がある7)。コンバ
ージョンでは用途変更や設備更新が不可欠なため、これらの改修に 必要とされる空間ヴォリュームや性能を確保するために相当量の改 修や改造が想定される。また優れた近・現代建築では建物各部位を 構成するディティールデザインが文化遺産的価值を担保している場 合が多く、これらの部位の安易なデザイン変更が建物全体の価值を 損なう可能性も指摘される ${ }^{8,9)}$ 。さらに近・現代建築は手を入れた 部分が既存のものと明解な対比を成さない分より慎重な対応が求め られる。このような特徵を持つ近・現代建築のコンバージョンでは、 建物の改修計画に先立って既存建物の文化遺産的価值を再評価し保 存すべき対象が建物の「どの部位」「どのディティール」にあるかを 見極め整理する必要がある。この整理作業を本稿では部位別保存手 法とした。これは重要文化財の保存・活用で推奨される計画方法 ${ }^{10)}$ と手法的には同じであるが、既存建築に対する改造範囲が拡大する 分、他の様式建築の部位別保存とは異なった運用方法が必要になる と考えている。

\section{2. 研究目的}

通常、優れた近・現代建築のコンバージョンでは、文化遺産的価 值を堅持しようとする保存と将来活用のための改修が相互に別の意 図を有しており、このぶつかり合いのなかで設計が実施される。保 存する意図が曖昧になればコンバージョン建築の立脚する足元が不 確かなものとなり、また保存が障害となれば将来活用の機能が十分

\footnotetext{
* (株)田中雅美建築設計事務所 代表取締役·工修

Architect, Masami Tanaka Architect and Associates Inc.
} 
に果たせなくなる。このような設計図式の中で、本稿は既存建築の 保存部位や保存目的を決定する検討プロセスがコンバージョン建築 の価值を醇成する設計初動の重要な段階と想定している。

建物の「どの部位を保存するのか」という問いは、「保存する目 的は何か」という観点と対照して考えられる。近・現代建築コンバ ージョンの保存目的は二つの観点から論考されることが多い11,12)。 1 番目は対象建築の文化遺産的価値を「史料」と寸る保存。この場 合は対象となる建物部位をオリジナルのままに保存することが求め られる。2 番目は対象となる建物部位を「記憶の契機」として保存 し、歴史や景観の継承を目的とした保存である。この場合、「記憶 の契機」となる建築の根本的構成要素は保存寸るが、その他の構成 要素は改造を許容する保存である。この二つの保存目的は対象建物 全体として二者択一ではなく、対象建物を部位別に仕分け文化遺産 的価值と改修目的を検討したうえで部位別に設定され、これに沿っ た保存形式を選択寸る必要があると考えられる。この考え方を前提 として、本稿は保存部位と保存目的を決定する検討プロセスについ てヘルシンキ市の事例を検証し「部位別保存手法の運用事例研究」 として論考したものである。この論点について研究したものは少な く、本論ではこの点についての知見を得ることを目的とした。

\section{3. 研究手順}

本稿は既存建築の保存部位・目的を決定するための法律が確立し ているヘルシンキ都心部で実施されたコンバージョン建築を調查事 例とした。ヘルシンキ都心部が都市計画において保護環境下にある ことは既往研究 ${ }^{13}$, 14) によって検証されている。研究論旨を展開す るにあたり第一に保存に関わるフィンランドの法的枠組みの中でへ ルシンキ市が実際にどのような行政を実施しているのかを正確に把 握する必要がある。この点に関する詳細な情報は希薄であり本稿前 段はこの点を整理し記述する。後段は調查事例において、保存部位・ 目的を検討する作業プロセスを行政資料と現場調查を研究資料とし て論考する。調查手順は 3 段階とし、1.フィンランドの建築保存に かかわる法制度と施行機関を整理する (4 章)。2. 法制度の中で「保 存部位・目的」を規定する地区詳細計画の構成と保存規定内容を確 認する (5 章)。3. ヘルシンキ都心部で実施されたコンバージョン 事例を抽出し地区詳細計画に示される「保存すべき部位」を部位別 に調査し、そこで示された保存目的とコンバージョン改修による活 用目的を確認する (6 章)。調查（2006 年〜 12 年）はヘルシンキ市 都市計画局を軸に関連する官公庁（表 1）に調查目的を明示し、ヒ ヤリングと資料の提供を求め収集した。

\section{4. 建築保存にかかわる法制度と行政区分}

フィンランドの建築保存にかかわる法制度は大きく 2 系統に分け られる (表 1 )。第 1 系統は国の重要な建築や区域を文化財として国 が保存指定する法制度で、「建造物保護法」（Rakennussuojelu Laki/Act on the Protection of Buildings）が基幹法としてそれに 該当する。法の施行は教育省管轄下の考古局注 ${ }^{1)}$ がこれにあたる。 第 2 系統は日常的な社会活動の中で通常発起寸る土地利用や建築に 係る法制度で、「土地利用と建物の法律」(Määnköyttö ja Rakennus Laki/Land Use and Building Act) 注 2) がこれにあたる。国家指定 の保護建築物を除く既存建築コンバージョンにおいては本法が基幹
法となる。このためコンバージョンしようとする既存建築が文化遺 産としての価值を保有するか否か、また価值を保有するとすればそ の価值をどのように保存するかについての保存規定は本法に準拠す る。具体的な保存規定は土地利用計画の中で示される。

\section{5. 土地利用計画の構成と保存規定 5-1. 土地利用計画の構成}

土地利用計画は広域; 地域計画 (Maakuntakaava/Regional Plan)、 中域; 地区総合計画 (Yleiskaava/Local Master Plan)、小域; 地区 詳細計画 (Asemakaava/Local Detailed Plan)の3 階層で構成される (表 1)。地域計画は複数の地方自治体からなる地域連合 (Maakunta liitto/Regional council) が作成する。地域計画に示される保存対象 は、考古局が全国に指定する保存地域/VAT(Valtakunnalliset alueidenkäyttötavoitteet/Nationally valuable Cultural historical environment) および建築注3) が中心で、そこに各地域連合計画局が 独自に選定した地域と建築が加算される。

地区総合計画と地区詳細計画は各地方自治体によって作成される。 地区総合計画は地区詳細計画の上位計画として自治体全体の土地利 用計画を示し、保存についは上位計画である地域計画に示される保 存地域、保存対象建築を踏襲したうえで自治体独自の保存区域を示 す。地区詳細計画は地区総合計画域内の小域の土地利用計画で、こ こで既存建築の個別の保存規定を示す。

\section{5-2. ヘルシンキ地区総合計画 2002 に示される保存区域}

ヘルシンキ市は地区総合計画を 1923 年、1960 年、1992 年と更新 してきた。現在の計画は 2002 年に作成（2003 年 11 月 26 日議会決 議）されたものである。土地利用は 17 分類注4) あり計画図では色別 され示される。保存区域注 5) は「文化、建築、景観の観点から重要 な区域」として斜線による網がけで区分図の上に重衫て示される(表 3 )。計画で示される保存区域の特徵や区域選択の根拠はへルシンキ 地区総合計画解説書 2002 注 6) $に$ 記載される。『保存区域の背景』と してユネスコの世界遺産、Dcomomo、また上位計画であるウーシマー 地域計画を挙げている ${ }^{15)}$ 。『区域選択の基礎』では「ヘルシンキ市 都市計画局とヘルシンキ市立美術館が地区ごとに作成している保存 台帳注 7) (Inventointi / Inventory）を計画の基礎とする」としてい る ${ }^{16)}$ 。『区域選択の根拠となる基準』では、「対象の審美的、歴史的 価值やそれを性格づける建築や景観」を選択基準としている ${ }^{17) 。 こ ~}$ こで記載されている選択基準（kriteereja/Criteria）は要点をま とめ表 3 の保存対象選定基準に示す。この節で市史の多様性を映し 出す 16 種類の環境タイプ注 8) に言及しその特徵が顕著に残る区域の 重要性が記載されている(図 1)。『区域の捉え方』は、「区域の中に は歴史や特徴を映す象徴となる建築があるが、そこに繋がる周囲の 環境もたとえ現在は明らかになっていなくても精査する価值があ

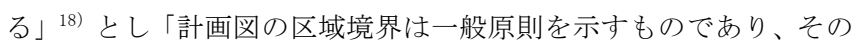
あり様は地区詳細計画で検討される」 ${ }^{19)}$ として、建築単体と群の相 関関係を説明している。『築年の若い建築の重要性』では、「対象建 築の築年数は重要ではあるが環境の価值は時間の経過を透視図的に 捉える必要があり、特に 1940 年代 50 年代の建物が大規模な改修時 期を迎えており、この年代に建てられた建築の価值を精査する必要 がある」 20) として、特に 1940 年以降の近・現代の建築遺産を保存 
表 1 Legal system and administrative section about preservation

\begin{tabular}{|c|c|c|c|c|c|c|c|}
\hline 行政区 & 官公庁 & 施行機関 & 法律 & $\begin{array}{l}\text { 保存地域 } \\
\text { (alue/area) }\end{array}$ & $\begin{array}{l}\text { 保存対象物 } \\
\text { (kohde/spot) }\end{array}$ & \multicolumn{2}{|c|}{ 保存体系 } \\
\hline \multirow{6}{*}{$\begin{array}{c}\text { 国 } \\
\text { Val takunta/country }\end{array}$} & \multirow{6}{*}{$\begin{array}{l}\text { 教育省 } \\
\text { Opetusminter / } \\
\text { Ministry of } \\
\text { the Education }\end{array}$} & \multirow{6}{*}{$\begin{array}{c}\text { 考古局 } \\
\text { Museovirasto } \\
\begin{array}{c}\text { National Board of } \\
\text { Antiquities }\end{array}\end{array}$} & - & VAT (RKY) & - & \multirow{6}{*}{ 指定 } & \\
\hline & & & $\begin{array}{c}\text { 建造物保護法 } \\
\text { Rakennus suo } \\
\text { Laki }\end{array}$ & - & 276対象物 & & \\
\hline & & & $\begin{array}{l}\text { 国有建物保護法 } \\
\text { Asetus val val ion } \\
\text { onistaminen } \\
\text { rakennus suoje lusta }\end{array}$ & - & 193対象物（800建物） & & \\
\hline & & & $\begin{array}{c}\text { 建築伝統保護法 } \\
\text { Laki rakennusper innon } \\
\text { suojelusta }\end{array}$ & - & 1対象物 & & \\
\hline & & & $\begin{array}{c}\text { 教会法 } \\
\text { Kirkko Laki }\end{array}$ & - & $\begin{array}{c}1917 \text { 年以に前建設された } \\
\text { 教会 }\end{array}$ & & \\
\hline & & & $\begin{array}{c}\text { 史跡法 } \\
\text { Muinai smuisto } \\
\text { Laki }\end{array}$ & - & 城塞、要塞などの史跡 & & \\
\hline $\begin{array}{c}\text { 地域連合 } \\
\text { Regakunta } \\
\text { Regional Councile }\end{array}$ & $\begin{array}{c}\text { 環境省ELYセンター } \\
\text { ELY Keskus }\end{array}$ & $\begin{array}{c}\text { ウーシマー地域連合 } \\
\text { uudenmaan Littor } \\
\text { Uus imaa } \\
\text { Regional Council }\end{array}$ & $\begin{array}{c}\text { 土地利用と建物の } \\
\text { 法律 } \\
\text { MRL }\end{array}$ & 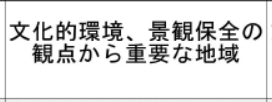 & $\begin{array}{l}\text { 文化的環境。䭪観保全の } \\
\text { 観点から重要な対象物 }\end{array}$ & $\begin{array}{c}\text { 地域計画図 } \\
\text { Maakunttakaava/ } \\
\text { Regional Plan }\end{array}$ & \multirow{3}{*}{$\begin{array}{l}\text { 土地利用 } \\
\text { 計画図 } \\
\text { Kaava/ } \\
\text { Pattern }\end{array}$} \\
\hline \multirow{2}{*}{$\begin{array}{l}\text { 地方自治体 } \\
\text { Kaupunki/city }\end{array}$} & \multirow{2}{*}{$\begin{array}{l}\text { ヘルルシンキキ市 } \\
\text { Helsingin Kaupunki } \\
\text { /Helsinki city }\end{array}$} & $\begin{array}{l}\text { 都市計画局 } \\
\text { 地区総合計課 }\end{array}$ & $\begin{array}{c}\text { 土地利用と建物の } \\
\text { 法律 } \\
\text { MRL }\end{array}$ & $\begin{array}{l}\text { 文化史的、建築的、暻観 } \\
\text { の観点から䔩要な域 }\end{array}$ & - & $\begin{array}{l}\text { 地区総合計画図 } \\
\text { Yle eskaava/ } \\
\text { Local Master Plan }\end{array}$ & \\
\hline & & $\begin{array}{l}\text { 都市計画局 } \\
\text { 地区詳細計画課 }\end{array}$ & $\begin{array}{c}\text { 土地利用と建物の } \\
\text { 洼侓 } \\
\text { MRL }\end{array}$ & - & $\begin{array}{c}\text { 対象物の保存嫢定が } \\
\text { 示される }\end{array}$ & $\begin{array}{l}\text { 地区詳細計画図 } \\
\text { Asemakaaaaa/ } \\
\text { local Detail Plan }\end{array}$ & \\
\hline
\end{tabular}

* 網掛された部分、特に濃い網掛部分は本調査の主要な対象を示す。

する必要性に言及している。『区域内の開発』は「活力ある都市の特 徵として持続的な刷新があるが、ヘルシンキの都市計画は「土地利 用と建物の法律」第 39 条により、既存環境・景観・自然の保護に 注意がはらわれねばならない」 ${ }^{21)}$ として既存環境のコンバージョン 計画下における保存に対する包括的な視点が示される。

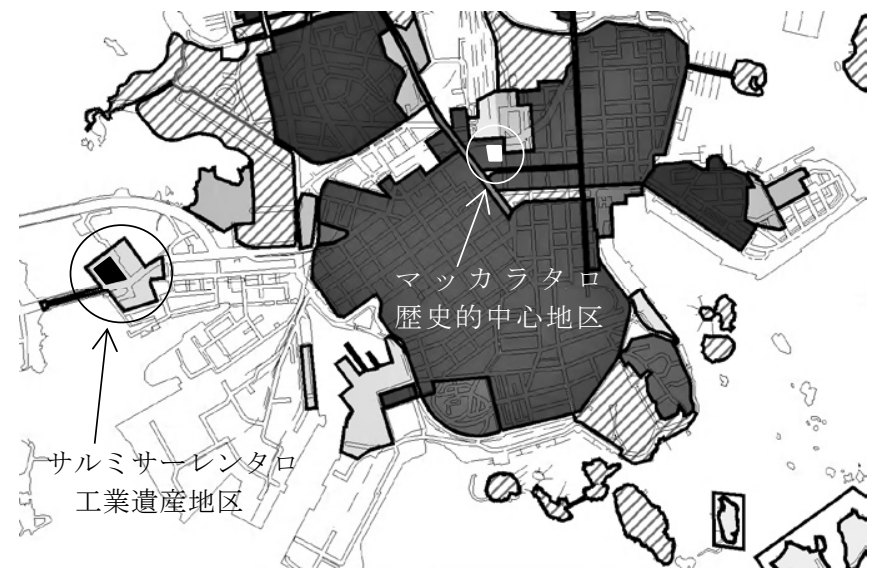

図 1 Helsinki Master Plan 2002 environmental type (Extracted heartland of Helsinki by author)

\section{5-3．地区詳細計画の部位別保存規定}

地区詳細計画は小域の土地利用計画でこの中で既存建築の具体的 な保存規定を示す。規定の内容は「保存すべき部位とその保存レべ ル」また保存要件として「保存目的・保存理由」の記載で構成され る。ヘルシンキ市は保存レベルを 3 段階とし最高ランク $\mathrm{sr}-1$ から sr-3 を通常使用している（表 2）注9)。保存規定の検討・作成は都
表 2 Preservation rule according to the part

\begin{tabular}{|c|c|c|}
\hline \multirow{3}{*}{$\begin{array}{l}\text { 保 } \\
\text { 存 } \\
\text { ル } \\
\text { ル }\end{array}$} & $\mathrm{sr}-1$ & $\begin{array}{l}\text { 顕著に高い建築的価値、一般的に歴史的にも景観的にも重要。多くはは } \\
\text { 内部空間にも価值がある。解体することは例外なく許可されない。 }\end{array}$ \\
\hline & $s r-2$ & $\begin{array}{l}\text { 高い建築的価値、歴史的にも景観的にも重要な建物。またはその部分 } \\
\text { を成す。しばしば内部空間にも価値がある。解体することは例外なく } \\
\text { 許可されない。 }\end{array}$ \\
\hline & $s r-3$ & $\begin{array}{l}\text { 価値ある建物の部分として保存する努カが求められる。增築も可能 } \\
\text { だがオリジナルの保護が求められる。解体された部分には可能な限り } \\
\text { 建物の復元が求められる。 }\end{array}$ \\
\hline \multirow{2}{*}{$\begin{array}{l}\text { 堡 } \\
\text { 要 } \\
\text { 件 }\end{array}$} & $\begin{array}{l}\text { 理 } \\
\text { 由 }\end{array}$ & $\begin{array}{l}\text { 保存理由は土地利用計画規則に明瞭に示されねばならない。対象建物 } \\
\text { の特徵的な形態やそれに基つくく価値を明示することが重要である。 }\end{array}$ \\
\hline & 貝 & $\begin{array}{l}\text { 対象建物の保存すべき特徵的な形態について正確に明瞭に規定する。 } \\
\text { 対象建物のオリジナル部分の保存、修復が第ーに求められる。修復が } \\
\text { 不可能な場合はオリジナルの意図に沿った修綪がなされる。 }\end{array}$ \\
\hline
\end{tabular}

市計画課・地区詳細計画課地区担当官と環境係建築保存専門官が協 議し計画を進める。保存レベルは既存建築の改修計画では最も重要 な与条件のひとつとなるため、地区詳細計画課はプロジェクトの重 要性に応じてヘルシンキ市立美術館文化環境係 (Helsingin Kaupunginmuseo Kulttuuri Ympäristö/City Museum of Helsinki Cultural Environment)に対象建築の歴史的、文化的価值を諮問し、 保存要件についての声明(Lausunto/Statement)を求めることが通 常である。また対象建築の重要度が高く社会的影響が大きい場合に は、考古局に声明を求める場合も多い。この関係当局間の連携方法 はフィンランドの既存建築の保存・活用を推進する上で要点のひと つである。表 3 は地区総合計画と地区詳細計画の相互関係が分かる ように事例 2 (サルミサーレンタロ）を取り上げて整理したもので ある。また同表に保存規定内容、保存対象選定基準注 10) および保存 選定のための基礎資料を合わせて整理した。 
表 3 Constitution and preservation rule of the figure of land use plan

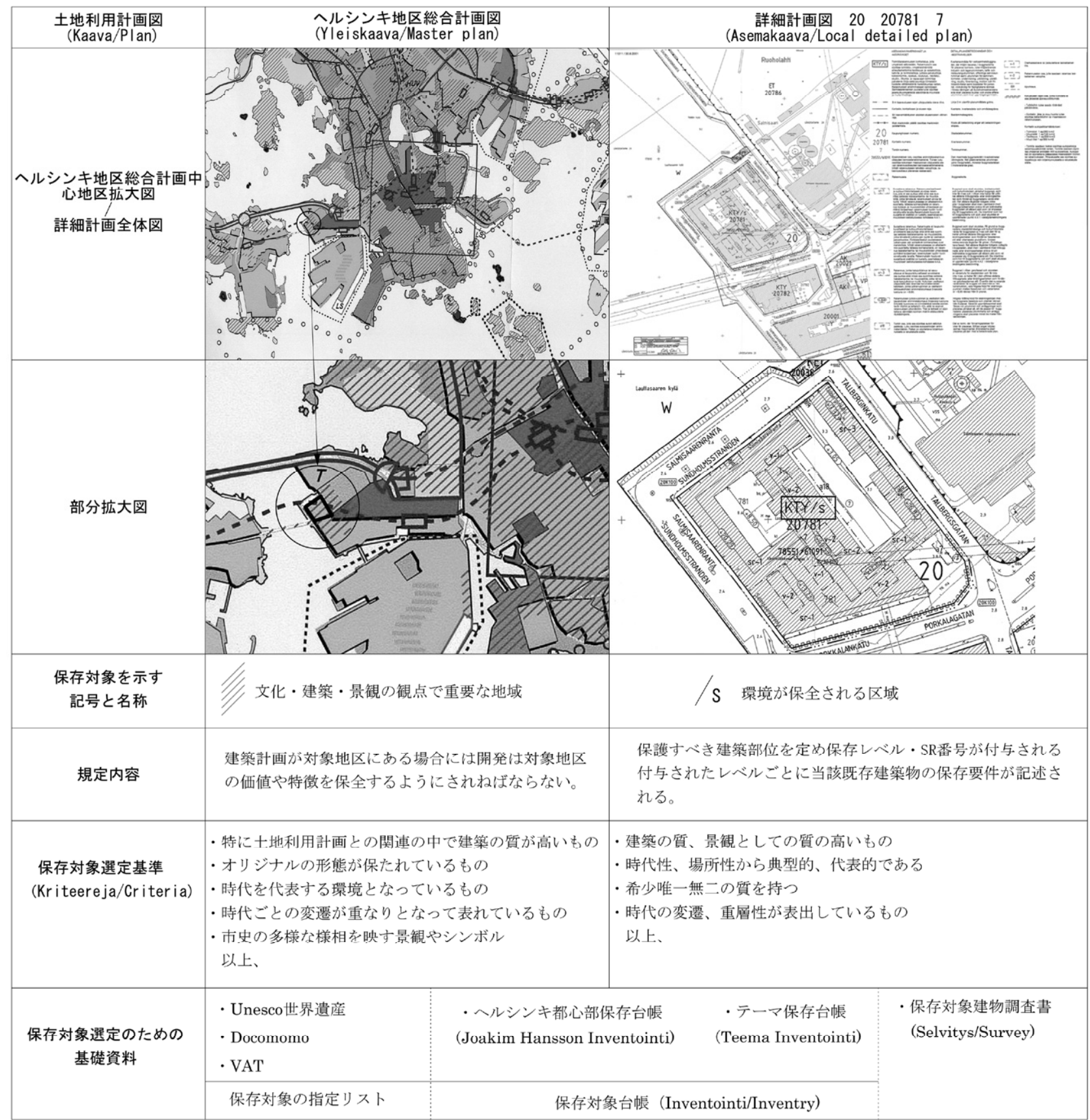

\section{6. コンバージョン事例にみる部位別保存手法の運用事例}

\section{6-1.コンバージョン事例調査}

地区詳細計画図で示される部位別保存規定がどのような検討過程 を経て決定されたのか。そしてその結果がどのようにコンバージョ ン建築の創出に作用しているかを考察するために、本稿では 1940 年代以降に竣工した近・現代建築の 2 つのコンバージョン事例を取 り上げ調查した。事例はともにヘルシンキ都心部に位置するが、コ ンバージョンの計画内容は以下の 2 点において相違する。(1)対象建 物はへルシンキ地区総合計画に示される異なった環境タイプに属す る。(2)コンバージョンの目的/用途変更の内容が大きく相違する。調 查手順および調查内容整理する。1. 地区詳細計画および同解説書か
ら保存規定を確認し、現場にて保存部位を調查する。2．将来活用を 意図した改修目的と部位別保存規定の双方を与条件として創出され るコンバージョン建築を確認し部位別保存手法の運用方法について 考察する。

\section{6-2. 事例 1、マッカラタロにみる部位別保存規定と改修計画}

対象建物はへルシンキ駅の正面に位置する 9 階建ての商業施設シ ティセンター/City-Center で、地区総合計画の環境タイプでは歴史 的中心地区に属している（図 1)。建物はマッカラタロ/Makkaratalo と呼称されるが、その由来は建物 3 階に設計された駐車場の車路(バ ルコニー）が建物立面にソーセージ/Makkara（マッカラ）のように 
張り出していることにある (写真 1 左)。設計者 Viljo Reve1122, 23 によって 1958〜60 年に設計された。建物は 9 階建ての L 字型で 2 つの前面道路に面し、L 字内側は 2 階建で 3 階は屋外駐車場となっ ている (写真 1 右)。3 階の駐車場へは、建物東側のケスクスカトゥ 通り/keskuskatu から屋内を貫通する車用斜路によってアクセス寸 る (写真 2 中, 右)。2000 年になると近い将来に予定されるケスクス カトゥ通りの歩行者専用道路化とヘルシンキ中央地区地下整備計画 注 11) の実施に呼応した不動産開発を目的としたコンバージョン計画 が発起した。計画は現在 3 階にある屋外駐車場を地下に下ろし、現 在 2 階建ての $\mathrm{L}$ 字中央部に 9 階建の商業と事務所からなる複合施設 を増床するものである（図 2）。

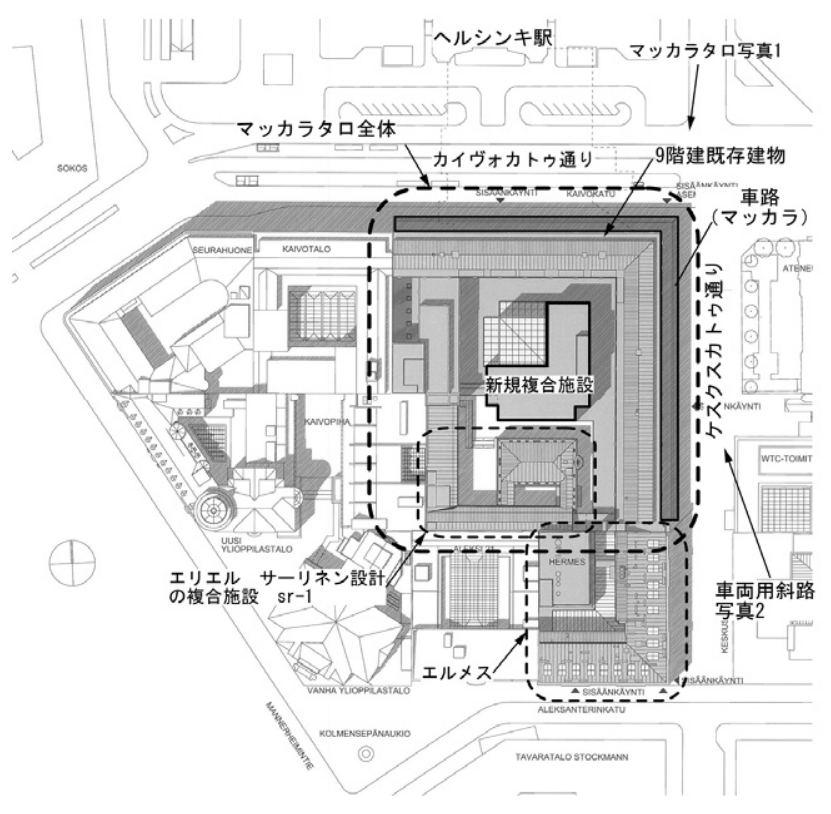

図 2 Figure of Makkaratalo conversion plan :マッカラタロ地区詳細計画変更説明書添付資料（CJN OY 作成） (囲い込み線、和名は著者作成)

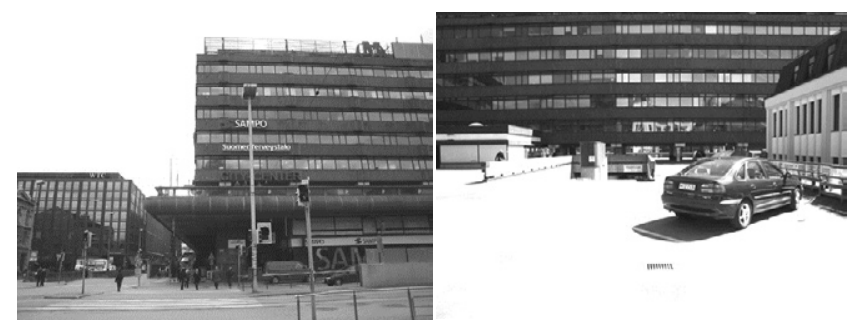

写真 1 Makkaratalo (before conversion)

左 : カイヴオカトゥ通りから見るマッカラタロ $/ 2007 / 5$ 著者撮影 右 : 屋外駐車場（正面に車両用斜路を見る） $/ 2007 / 5$ 著者撮影

コンバージョン計画の発起に伴って建物所有者は 2002 年 9 月に当 該地区詳細計画変更を求める申請を提出した。申請を受理した都市 計画課では現下の地区詳細計画を最新のものへ変更することになり マッカラタロの保存規定が検討された。保存規定の作成にあたって は、撤去となる屋外駐車場に機能上必要とされてきたバルコニー(駐 車場外周車路として利用）およびケスクスカトゥ通りから 3 階の屋
外駐車場にアクセス寸る車用斜路の取り扱い方、そしてその保存規 定に準拠して刷新される前面道路側ファサードの都市景観について 熟慮された。マッカラタロは竣工当時からバルコニーデザインの美 醜について市民的な関心を喚起した建築で、今回のコンバージョン 計画ではバルコニーの保存に関して幅広い市民的な議論が起こった 24) 注 12)。保存規定を作成する都市計画課の熟慮は、地区詳細計画変 更図を作成する過程で保存要件に関してヘルシンキ市立美術館と考 古局に対して数度にわたり（2003 年 12 月、 2004 年 8 月、2004 年 11 月（考古局のみ）、2005 年 3 月）保存要件に関わる声明を要請した ことで推察できる。さらに 2004 年 11 月に都市計画課はマッカラタ ロのコンバージョンによって新たに創出される都市景観を勘案する ために独自に検討用資料注 13 ) を作成した（写真 3)。これら一連の過 程は 2005 年 3 月 10 日のマッカラタロ地区詳細計画変更に関するへ ルシンキ都市計画委員会注 14 ) 会議議事録注 ${ }^{15)}$ にまとめられる。

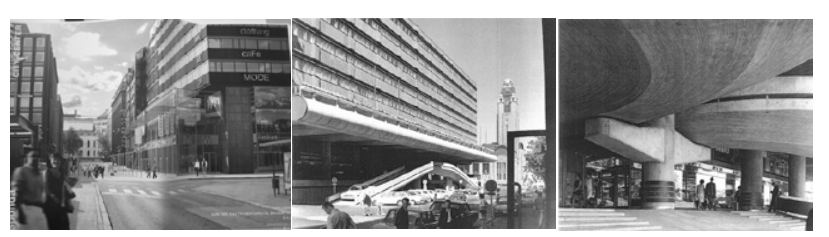

写真 2 conversion perspective view of the initial stage and existing car ramp

左 : 初期コンバージョン計画（2003 年）パース/バルコニーおよび斜路が撤 去された計画/建築事務所 CJN oy 作成 中：ケスクスカトゥ通りからマッカラタロ外観写真 右：ケスクスカトゥ通りから車両斜路の見上げ写真 $*$ 写真中、右はフィンランド建築博物館所蔵

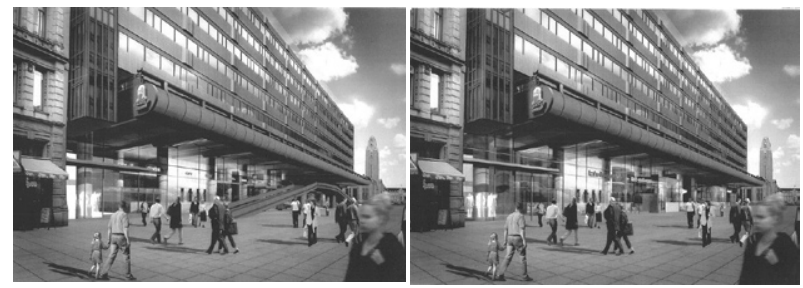

写真 3 Makkaratalo conversion street scene examination perspective view

左：マッカラおよび車用斜路を保存した場合の街路景観予想図

右 : マッカラ保存、車用斜路を撤去した場合の街路景観予想図 *左予想図、右予想図は共にマッカラタロの都市景観精査資料から

ヘルシンキ市立美術館と考古局は共に、バルコニーの保存ととも に「車用斜路は既存建物の本質的な価值を有する要素として重要で ある。」とする声明を最後まで堅持したが注 16$)$ 、都市計画局は「バル コニーおよび車用斜路の保存は、ケスクスカトウ通りの歩行者行動 を想定した環境改善の観点から判断するとし、バルコニーは保存、 斜路は解体撤去とする」と結論づけた注 17)。ヘルシンキ都市計画局 の作成した保存規定は、車用斜路の保存に関して考古局、ヘルシン キ市立美術館と見解を異にしたまま市議会承認された。この決定を 不服とした場合には行政訴訟を起こすことができるが、マッカラタ ロの場合には考古局、ヘルシンキ市立美術館とも告訴することはな かった。マッカラタロの地区詳細計画変更図（図 3) と保存要件（表 
4）には、前面道路に面する建物部分は sr-2、バルコニーおよび解 体撤去される車用斜路は通常使用される保存レベル番号ではなく、 バルコニー (uloke) 部分の保存要件として sr-u と特記された。

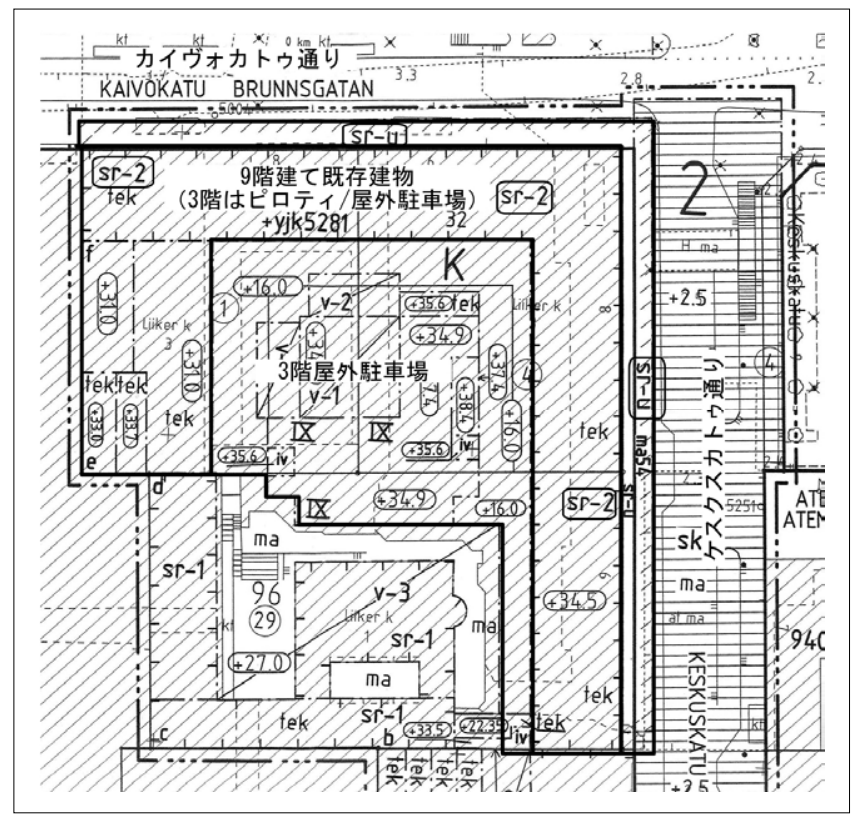

図 3 Makkaratalo Local detailed plan change figure

表 4 Mention about preservation rules according to the part

sr-2 保存すべき建物（sr-2）。都市景観的、建築的、文化的に貴重な建築 で、ファサードの形式や道路側の屋根の原型を損なうような増築や改 修を行うことはできない。もし以前にそのような行為が行われていれ ば、増築や改修をするときに建物の形式に最適な方法で修正しなけれ ばならない。

$\mathrm{sr}-\mathrm{u}$ 保存す心゙きバルコニー。カイヴオカトウ通りとケスクスカトゥ通り に沿ったファサードにある半円の端を持つバルコニーを残さなけ ればならない。バルコニー階はガラスの壁とし、上部階の立面と同 位置か内側としなくてはならない。バルコニーはカフェやレストラ ンのテラスとして使用することができる。ケスクスカトゥ通り側の バルコニー下の空間は建物保存の目的とケスクスカトゥ通りの歩 行者専用道路化に適した形で高水準に造らなければならない。バル コニー下の新しいファサードは、エルメスの壁のラインまで出るこ とができる。ケスクスカトウ通りとカイヴオカトウ通りの角のエレ ベーターシャフトの立面は既存ファサードの䨌囲気と素材、および ラウタティエントリ広場側の都市景観を残さなければならない。立 面に見られる建物当初の高い水準の柱、梁、及びバルコニー下側天 井のデザイン原理やオリジナリティーを復元しなくてはならない。

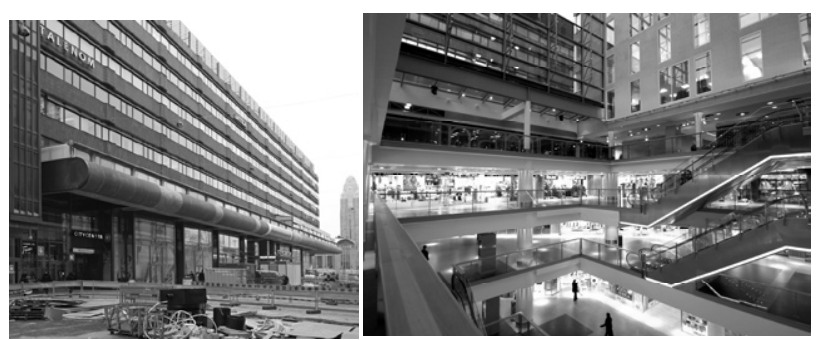

写真 4 Makkaratalo under construction 2016. 2, 2014. 2 左：マッカラタロの新しいファサード 2016.2 Jari Jetsonen 撮影 右: 新複合施設内観 2014.2 著者撮影
本事例は「記憶の継承」を旨とする建築要素の保存について、将 来への活用を見据えながら検討されたものである。決定までに 3 年 間を費やした保存規定は、その検討内容を深く内包した新しいファ サードデザインに結実した。この観点によってマッカラタロはコン バージョン建築がつくりうる新種の価值を提示している。

\section{6-3．事例 2、サルミサーレンタロの部位別保存規定と改修計画}

対象建物サルミサーレンタロ/Salmisaarenta1o は、国営酒造会社 アルコの本社屋、サルミサーリ工場、倉庫からなる複合生産施設で ある。1938 年から 1940 年にかけて指名コンペで一等を得た建築家 ヴァイノ・ヴァハカッリオ/Väinö Vähäkallio の設計図に基づき建 設された。「力感豊かに一塊となった赤レンガの建築は 1930 年代工 業建築の傑出した作品群に属する」注 18)（写真 5)。建築的にも景観 的にも重要な建築として、ヘルシンキ地区総合計画の環境タイプで は工業遺産地区に属している（図 1）。

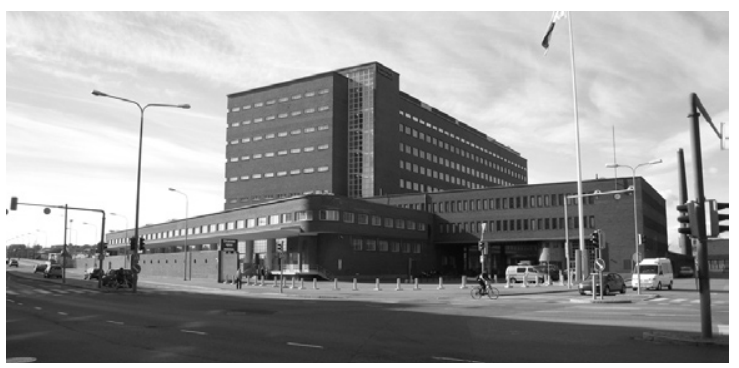

写真 5 Whole view (watch from Porkkalankatu street) by author 2007 年

建物の本来用途は 1999 年に幕を閉じた。 2000 年になると建物を ヘルシンキ管区地方裁判所に用途変更しようとするコンバージョン 計画が発起した。これにより地区詳細計画の変更申請が提出された。 都市計画課は 2001 年 3 月 12 日に建物関係者・団体を一堂に集め OAS 会議注 19) を開催した。その後 1 年間の作成期間を経て 2002 年 4 月 18 日に地区詳細計画変更図が議会承認された。サルミサーレンタロ 地区詳細計画変更解説書/Salmisaarental muutokusen Selostus p4 の 3 『地区詳細計画変更目的』では「主要な変更目的は建物の用途 変更そして建築的に高い水準で国家の工業の歴史を語る建物の保存 規定 $\left(\mathrm{sr}^{-1}-\mathrm{sr}-2, \mathrm{sr}-3\right)$ を設定し建築的にも景観的にも重要な建物を 保存することである」とした。同解説書 pp $4 \sim 5$ 4『地区詳細計画 変更の概要』の 4.3 『計画図にある既存環境』では「地区詳細計画 変更図は考古局の支援を受けて作成された」こと、また「同変更計 画図はサルミサーレンタロ報告書/Salmisaarentalo selvitys 注20) とプロジェクト改修計画（トゥオモ シートネン建築事務所 /Arkkitehtitoimisto Tuomo Siitonen 作成）を下敷きにして作成さ れた」としている。また同解説書 p5 4.4『計画図に示寸部位別保 存』では「本社屋、工場事務所、低層部分の倉庫は $\mathrm{sr}^{-1}$ 、高層棟の 工場は sr-2、低層実験棟のタルベルギンカトゥ通りおよびサルミサ ーレンランタ通りの外観、煙突は $\mathrm{sr}-3$ とする。また中庭、荷下ろ し、塀等は KTY $/ \mathrm{s}$ 注 21$)$ にって保存される」と記載。建物の部位別 保存レベルとコンバージョン計画を対照する（図 4)。なお以後本稿 では、本社屋の $\mathrm{sr}^{-1}$ 、高層棟の工場 $\mathrm{sr}^{-2}$ の部位別保存要件に着目 し考察する。 
従前用途と部位別保存レベルおよびコンバージョン後の用途

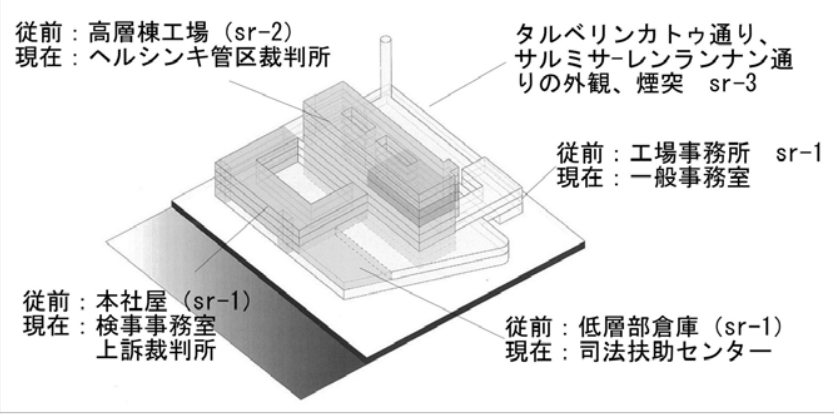

図 4 Preservation level according to the part (Arkkitehti 2011/2 pp28 Japanese sentence by author)

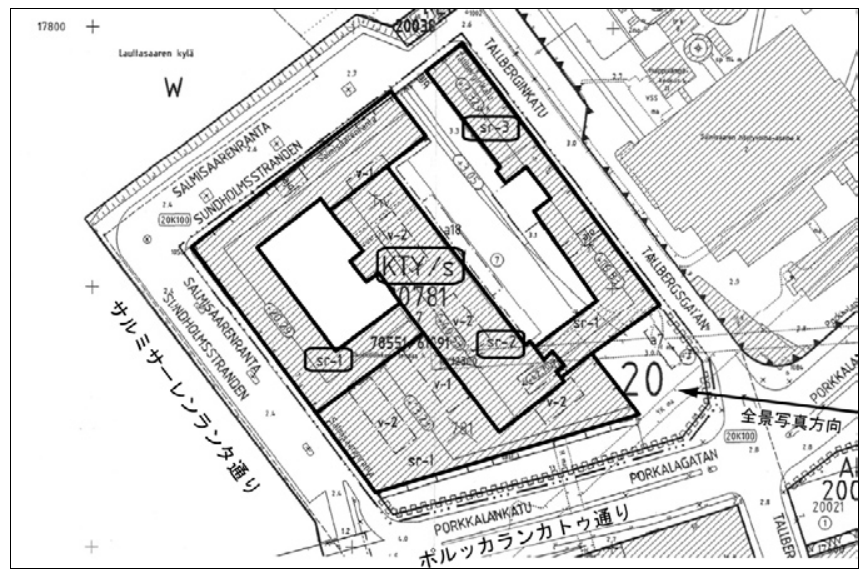

図 5 Salmisaarentalo local detailed plan (extracted) (図 5 の囲み線、和名、矢視図は著者作成)

表 5 mention about preservation rules according to the part

\begin{tabular}{|c|c|}
\hline 記号 & 規則（保存要件：理由·目的） \\
\hline $\mathrm{KTY} / \mathrm{S}$ & 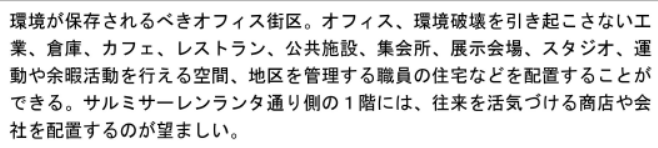 \\
\hline sr-1 & 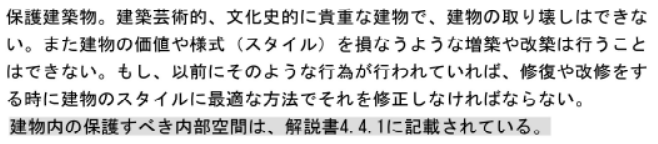 \\
\hline sr-2 & 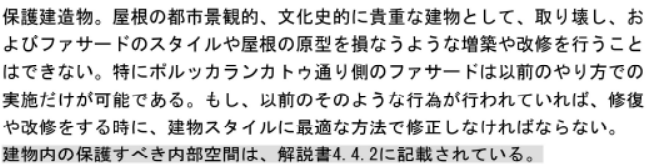 \\
\hline
\end{tabular}

サルミサーレンタロの部位別保存規定を同地区詳細計画変更図 (図 5）と保存規定（表 5）で確認する。この中で特に sr-1、sr-2 では 家具を含めた内部空間の保存について、同解説書で記載するとして おりこの部分について抜粋しまとめる（表 6)。sr-1 と指定される 4 階建ての本社屋は $3 、 4$ 階を検事事務室に、2 階部分の工場、倉庫は 上訴裁判所の法廷に用途変更された。サルミサーレンタロ全体の中 でこの部位は建築、インテリア、家具の高い価值が確認され保存規
定は $\mathrm{sr}^{-1}$ とされた。実際のコンバージョン計画では、既存建物の空 間サイズ、採光条件などが新しい用途と合致しやすい計画のために 大規模な躯体の改修は必要なく、sr-1 の保存規定下であっても保存 活用は十分に可能であった (写真 6 左)。

表 6 Mention of the local detailed plan

\begin{tabular}{|c|c|}
\hline 説明書 & 説明（保存要件） \\
\hline 4-4-1項 & 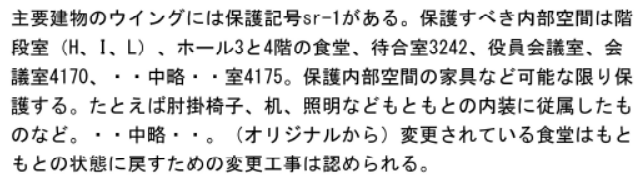 \\
\hline 4-4-2項 & $\begin{array}{l}\text { 工場や中央倉庫はすでに大部分が空になっており保護すべき家具はない。 } \\
\text { 保護すべき内部空間は階段室Aとエレベーターである。・・略・・他の } \\
\text { 工場と倉庫の内部空間は保護目的は与えられていない。 }\end{array}$ \\
\hline
\end{tabular}

さらに sr-1 の保存規定が適用される空間が地区計画変更解説書 において室単位で示されたために（図 6)、保存規定から除外された 空間は新しく設計（事務所の内部空間や、法廷など）されており(写 真 6 右)、sr-1 部位との明確な対比が確認された。 $\mathrm{sr}^{-1}$ 部位の保存 は史料とする保存であることから (写真 7 ) その中に建築の新しい創 造性はつくり得ないが、建築全体でとらえれば時間の混成という建 築構成が示されることとなる。
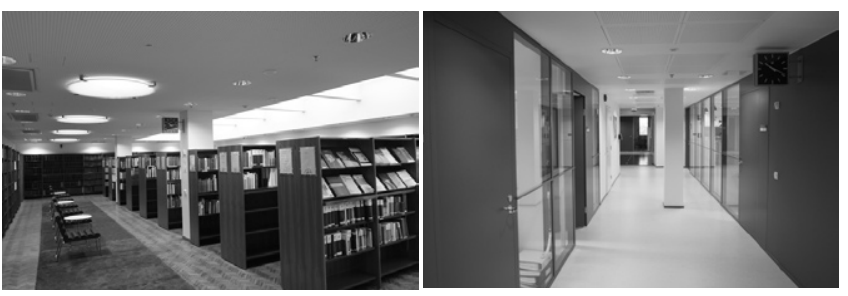

写真 6 Company building interior (after conversion)

左 : 図書室（従前は食堂）は用途変更したがインテリア空間は 1930 年代オ リジナルに復元されている。

右: 廊下と事務室、保存要件から除外された廊下と新規事務室。廊下の位置· 幅が改修され、従前は室内にあった柱が独立柱となり廊下に出た。
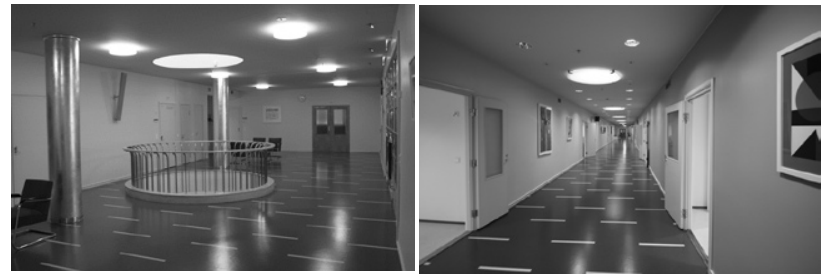

写真 7 Company building interior (after conversion)

左 : ホール 3、1930 年代のオリジナルに復元。

右 : 中廊下、1930 年代のオリジナルに復元。

$*$ 写真 6,7 は 2011 年著者撮影

保存規定 sr-2 とされた高層棟は酒造工場として建てられ、その生 産工程に則した平・断面構成となっている。上部階に原料をリフト アップし順次中間階へ生産プロセスを移しながら下層階では瓶詰、 梱包され出荷倉庫に格納される。階高は原料貯蔵を目的とした上層 
階が低く（写真 8 左）下層階に行くほど階高が増していく（写真 8 右)。この高層建物を裁判所に用途変更する計画では、来館者の出入 りが多く見込まれる法廷を下層階に、事務所空間を上層階に配置し た。新規平面構成（図 7）は、既存建物において床荷重を負担する 笠型の柱頭を持つ柱のスパンを基本に考えられた。事務空間では、 この柱を部屋の間仕切り間に (写真 9 左)、また法廷では独立柱とし て存在感を見せるように平面計画された（写真 9 右）。また高層棟の 内部深くまで光を取り入れ、建物内の生活環境を高めるためライト ウェルが設けられた（写真 10, 図 8)。ライトウェルの設置によって 床がキャンティレバーとなり柱の荷重負担面が拡大寸る部位では、 柱頭を増し打ちする柱デザインの変更が実施された（写真 11 左, 図 8)。上層階事務室では既存空が高空となってしまうため新たな横長

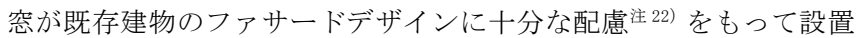
された (写真 11 中, 右)。また新規空調システム導入のために屋上に 新規空調機械室が必要となった。新規空調機械室は地区詳細計画保 存規定に準拠し注 ${ }^{23)}$ 既存建物のパラペットラインから 3 メートルの 壁面後退距離をもって計画された(図 8)。
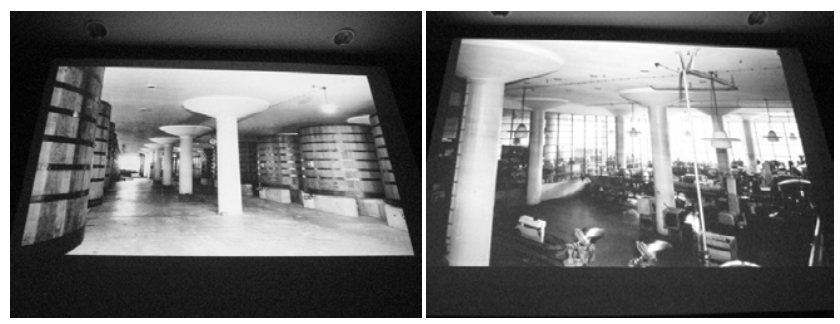

写真 8 introspection in past time

左 : 従前高層棟上層階醸造庫内観；サルミサーレンタロ事務局提供

右：従前高層棟 1 階瓶詰工場内観；サルミサーレンタロ事務局提供

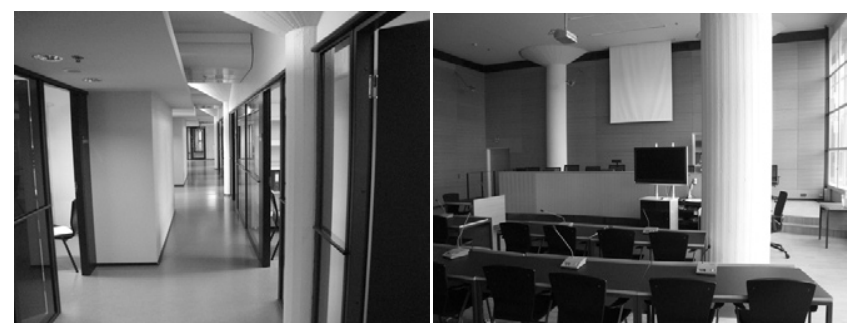

写真 9 High-rise building introspection after conversion 左 : 現況高層棟 上層階事務室中廊下、柱が間仕切りの位置にある

右：現況高層棟 3 階法廷内観、柱が独立して存在感を主張 *2007 年 著者撮影
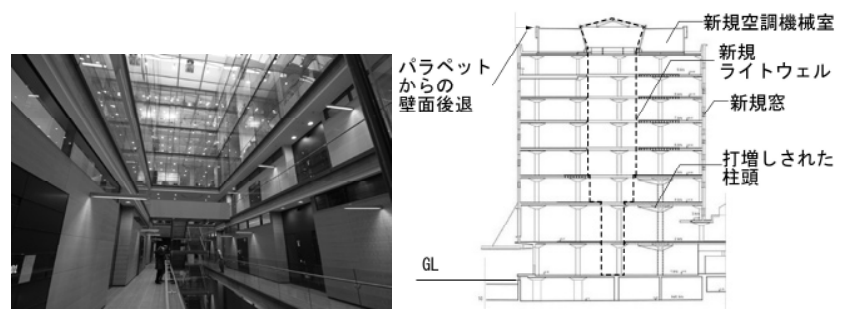

写真 10 Light wells introspection 図 8 Section 写真 10 高層棟ライトウェル 3 階から見上げ : 著者撮影 2007 年 図 8 高層棟断面図 : betoni 12005 pp11、説明は著者作成
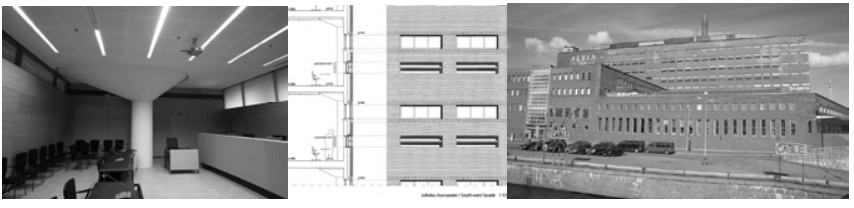

写真 11 Indipendence reinforced pillar in the court and the new window in the west elevation

左：現況高層棟 3 階法廷内観、柱頭打ち増し独立柱を見る；著者撮影 2007

中：高層棟西側外壁新設空断面詳細および立面；Arkkitehti 6/2005 p36 南西立面図

右 : コンバージョン後のサルミサーレンランタ通り側西側立面、 高層棟の細長の新設空を見る; 著者撮影 2007 年

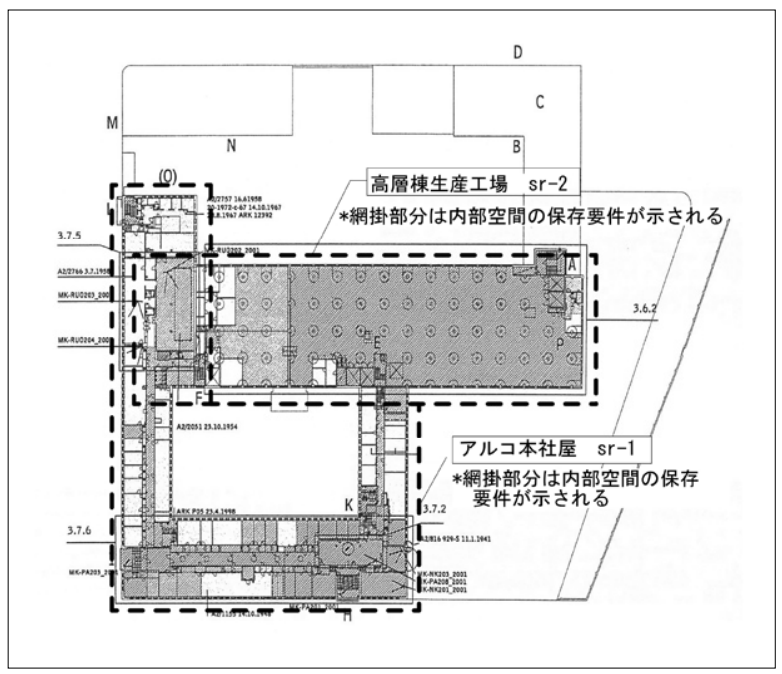

図 6 4th floor plan indicating the preservation rule according to the part $(3 \mathrm{~F} / 4 \mathrm{~F})$

従前建物の部位別保存を示す；サルミサーレンタロ地区計画変更説明書 添付資料 p89/Salmisaarentalo KORTTERI20781 ASEMAKAAVAN MUUTOKSEN NR011011SELOSTUS p89 より出展

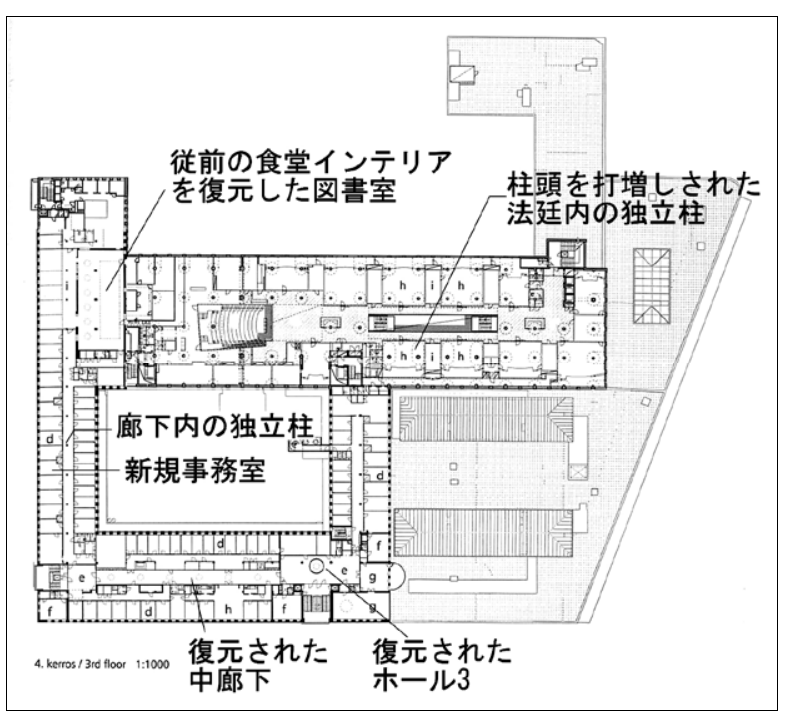

図 7 conversion 4 th floor plan (3F/4F)

Arkkitehti6. 2005, pp35, 4. kerros/3rd floor 1:000 と同誌 2. 2011, pp29 4. kerros/3 $3^{\text {rd }}$ floor 1:000 を合成し作成 した新規 4 階/ 3 階平面図（日本語説明は著者作成） 
本事例を見ると保存規定 sr-2 では通常認められないような外観 デザインの改変と考えられる新規空設置やライトウェルによる中央 床の撤去および柱頭デザインの変更等の大掛かりな躯体に関わる改 造が実施されている。sr-2 によって既存建物の重要なデザイン要素 を保存しながらも、用途変更に伴って必要とされる新しい空間やガ ラスを重用したライトウェルの今日的なデザイン要素取り入れたこ とによって、建築に時間軸を取り込んだ新しい空間創造の可能性が 提示された。本事例は建物所有者及び改修設計者と都市計画局がコ ンバージョンの目的を相互認識したうえで地区詳細計画変更保存規 定が作成されたことを明確に示寸ものである。この相互作業がコン バージョン建築の保存規定に柔軟性を与えるとともに、新規用途へ の対応の質を高めている。

\section{7. 結語}

1. ヘルシンキ都市計画局は既存建築の保存部位・目的を地区詳細計 画で規定するが、事例調查から地区詳細計画の立案作業において保 存規定に関わる検討では部位別保存手法を運用していることが確認 された。保存規定は保存レベルと保存要件で構成される。保存レベ ルは重要性に応じて通常 $\mathrm{sr}^{-1}, \mathrm{sr}-2, \mathrm{sr}-3$ の 3 段階に分けられ運用さ れる。 sr-1 として規定された保存部位は史料とすることを目的とし、 sr-2 または sr-3 として規定された保存部位は記憶の契機を目的と している。保存要件は保存の理由と目的が記述される。

2. 事例 1 の建物はヘルシンキの中心部に位置する。ヘルシンキ都市 計画局はこの建物の保存規定を決定するために多くの時間を費やし とりわけ慎重に検討した。この間、都市計画局はヘルシンキ市立美 術館と考古局に立案作業段階から保存要件を諮問し声明を得るとい う過程を繰り返した。決定された保存規定は新しいコンバージョン 建築のファサードデザインに結実しており、保存規定がコンバージ ヨン建築のデザインに重大な影響を持つことが示された事例となっ た。事例 1 はコンバージョン建築において保存の意味を根本から問 いかけており、この点において新築建築とは異なる新種の建築価值 を提示した。

3. 事例 2 はコンバージョン計画の中で用途変更に際立った特徵を持 つ。近代建築遺産としての価值が認められた既存建築は, 新規用途を 見据えながら部位別に仕分けられ保存レベルが決められた。 $\mathrm{sr}-1$ 部 位は史料としてオリジナルに復元し保存された。sr-2 部位は既存建 築の特徵ある空間構成を具現している柱を保存要素として堅持しな がら、新規用途で必要とされる空間機能のために相当量の改造が実 施された。保存と改修のそれぞれの異なった意図が明確に反映され ながらも、二つの目的は融合し歴史的時間軸を取り込んだ新たな空 間が構築され、コンバージョン建築によってつくり得る建築創造の 可能性を提示した。

4.ヘルシンキ市都市計画局はコンバージョン計画の発起に合わせて 地区詳細計画を更新する。地区詳細計画の更新作業は OAS 会議をも ってスタートし、地区詳細計画を勘案する初期段階から既存建物の 再評価とコンバージョン目的を下敷きとして見据え、部別保存手法 を運用している。この運用方法が保存目的とコンバージョン目的を 相互に近づけ、保存の在り様に柔軟性と多様性をもたらしコンバー ジョンの建築的創造性に新たな可能性を広げている。

\section{謝辞}

本調査を行うにあたり、ヘルシンキ都市計画局のリータ サラステ イエ氏をはじめ多くの方々、環境省既存環境局、ならびに考古局の シルッカリーサイェッツォネン氏には多大な協力をいただき、ここ に謝意を表します。

\section{参考文献}

1) 足立裕司ほか 12 名: 再生名建築，再生建築の分類 - 類型，足立裕司，p192 鹿島出版会, 2009.9

2) 藤森照信 : 建築知識, 別冊ハンディ版, 建築保存再生学科入学のす寸め、 pp9 10, (株) 建築知識, 1983.1

3) 鈴木博之 : 現代の建築保存論, p80, 王国社, 2001. 12

4) 長谷川豪：JA73，リノベーションの現在性， $p p 8$ 9 , 新建築社, 2009

5) 足立裕司ほか 12 名: 再生名建築, 再生建築小史, 内田青藏, p183, 鹿島出 版会, 2009.9

6) 谷泰人ほか 3 名 : ドイツにおけるコンバージョン事例の調査研究, 日本建 築学会大会学術講演梗概集 F-2，pp801～802，2008．9，など一連の研究

7) 倉方俊輔 : 10+1, No. 49, モダニズム建築の保存はなぜ難しいのか? pp114-115, INAX 出版 2007. 12

8) Kairamo Maija, Sippo Hanni : Arkkitehti, Repairing Alvar Aalto's building, p24, 2001. 5

9) Kairamo Mai ja: Arkkitehti, Lesson's in restoration, p25, 2007.2

10）重要文化財（建造物）保存活用計画策定指針 文化庁文化財保護部 1999. 3

www1. city. matsue. shimane. jp/shisei/jouhou. . /h24.../shiroyu2. pdf (参照 2013.9.29)

11) 鈴木博之 : 現代の建築保存論, $p p 77^{\sim} 79$ 王国社 2001.12

12) 清水重敦 : 10+1, N0.44, 「先行建築学の寸寸めバイパスとして藤森式都 市建築保存論」作らない建築学, pp120-125, INAX 出版, 2006.9

13) 堀内絢子 : タピオラ田園都市の保存に関する考察, 日本建築学会計画系論 文集，Vol 74，No646，pp2723-2730，2009. 12

14) 堀内絢子 学位論文 フィンランドにおける二十世紀建築遺産保護の研究

15) ヘルシンキ地区総合計画解説書 2002 Helsingin Yleiskaava ehdotus Selostus2002, 2003.6.17 から 11.6.1「Taustaa/背景」p169, （引用抜粋、 著者翻訳)

16) ヘルシンキ地区総合計画解説書 2002/Helsingin Yleiskaava ehdotus Selostus2002，2003.6.17 から 11.6.2「Alueiden valintaperusteet/区域 選択の基礎」 $\mathrm{p} 174$ ，（引用抜粋、著者翻訳）

17) ヘルシンキ地区総合計画解説書 2002/Helsingin Yleiskaava ehdotus Selostus2002，2003.6.17 から 11.6.2「Alueiden valintaa ohjannut kriteeristö/区域選択の基準」p174，（引用抜粋、著者翻訳）

18) ヘルシンキ地区総合計画解説書 2002/Helsingin Yleiskaava ehdotus Selostus2002，2003.6.17 から 11.6.2「Alueiden valintaa ohjannut kriteeristö/区域選択の基準」, p175 から（引用抜粋、著者翻訳）

19) ヘルシンキ地区総合計画解説書 2002/Helsingin Yleiskaava ehdotus Selostus2002, 2003.6.17 から 11.6.5「Kulttuurihistoriallisesti, rakennustaiteellisesti ja maisema- kulttuurin kannalta merkittävien alueiden kehittäminen/文化・建築・景観の観点で重要な地域の開発」p180 から（引用抜粋、著者翻訳）

20) ヘルシンキ地区総合計画解説書/2002 Helsingin Yleiskaava ehdotus Selostus2002, 2003.6.17 から 11.6.3「Nuoremman rakennuskannan nousu kulttuurihistoriallisen arvottamisen kohteekisi/築年の若い建築の重 要性の向上」 $\mathrm{pp} 176^{\sim} 177$ から（引用抜粋、著者翻訳）

21) ヘルシンキ地区総合計画解説書 2002/Helsingin Yleiskaava ehdotus Selostus2002，2003.6.17 から 11.6.5

$\lceil$ Kulttuurihistoriallisesti, rakennustaiteellisesti ja maisemakulttuurin kannalta merkittävien alueiden kehttäminen/文化・建築 • 景観の観点で重要な地域の開発」p180 から（引用抜粋、著者翻訳）

22) Jetsonen Srkkaliisa:20th-CENTURY ARCHITECTURE FINLAND, Humane Rationalism Themes in Finnish Architecture of 1950s, p95, Museum of Finnish Architecture,

23)アスコ・サロコルピ，向後英一訳 : 現代フィンランド建築，p51, 形象社, 1972. 10.30 
24) Rauske Eija : Finish architecture 1900-2000, p99, Museum of Finnish Architecture, 2008

\section{注}

注 1) 考古局 (Museovirasto/National Board of Antiquities) は国の文化遺産 の調查・研究組織であると同時に、歴史文化的に価值のある既存環境の保 全に関わる機関である。局は教育省 (Opetusministeriö/The ministry of education) に所属しているが、独立性があり国家予算に歳費が計上される。 http://nba. fi

注 2) 本法は都市計画と建築を統合した法規範で、土地利用計画に関わる各条 項、建築にかかわる各条項および土地利用計画の決定を不服とした場合の 行政訴訟制度で構成されている。本法には構造、設備、防苂などの技術基 準は包含されておらず、本法第 13 条（フィンランド建築規準集）において 必要とされる技術基準は環境大臣によってフィンランド建築規準集 (Suomen rakentamismääräyskokoelma/The National Building Code of Finland）にまとめるとしている。

注 3) 考古局は保存対象を指定するが具体的な保存規定を示すことはない。対 象建物が改修される場合は、他の建物と同様に各自治体の都市計画課が作 成する地区詳細計画の中に保存規定を記載する。ただし都市計画課は作成 中の保存規定案に対し考古局の同意を得る必要がある。

注 4) 17 分類の土地利用目的のうち市民の日常生活と身近に関連寸る土地利 用は 8 種類に分類される。中心地域、中層建物地域（集合住宅、公共施設 など）、戸建住宅地域、行政施設地域、業務地域、インフラサービス、市 立公園、リフレッシュ地域である。他の土地利用目的は交通施設地域、港 湾、軍基地、自然保護、Natura 地域、世界遺産、水域、中央公園、プロジ エクト計画地域（この地域はより詳細な土地利用が部分地区総合計画に示 される) の 9 種類が示される。

注 5) 保存区域の指定は「土地利用と建物の法律」第 39 条（地区総合計画で 検討されるべき内容）第 8 項「既存環境、景観、自然の保護」に準拠して いる。

注 6) 土地利用と建物の法律（Määnkäyttö ja Rakennus Laki/Land Use and Building Act 以後 MRL と略) 第 40 条で規定された地区総合計画の解説書。 解説書では計画目的、計画の選択肢や効果また地区総合計画の根拠となっ た情報を記載しなければならないとしている。

注 7）ヘルシンキ都市計画局は保存台帳として、都心部建物保存台帳 (Kantakaupungin rakennussuojeluinventointi/City center building preservation inventory) とテーマ別保存台帳 (Teemakohteiset inventointi/Theme inventory)を作成している。都心部保存台帳は 1990 年 から 91 年ヨアキム・ハンソン/Joakim Hansson によって編集された。都心 部に存在する建物の中から 1600 の建物を選定し作成された保存台帳。テー マ別保存台帳はテーマごとの保存台帳で、学校、階段、屋根形状などのテ 一マ別に作成されている。ヘルシンキ市立美術館は文化環境課 (Kulttuuriympäristö/Cultural environment) で建築保存台帳を作成する。

注 8）へルシンキ地区総合計画 2002 では文化史的に建築的にそして景観の観 点から重要な環境を 16 タイプに分類し規定している。へルシンキ中心部は 広範囲に歴史的中心地区と規定され、その周囲に 1940 50 年代中高層集合 住宅地区、工業遺産地区、別荘環境地区、景観として重要地区などが取り まくように規定されている。

注 9）表 2 はヘルシンキ都市計画局が局内資料として作成した既存文化的環 境一詳細計画図保存規定策定の原則/Rakennettu kulttuuriympäristö asemakaavan suojelu-määräysten laatiminen periaatteet 3.2 .1 . 建物に かかる保存規定, 保存レベル, pp 20 から著者が拔粋・翻訳し表形式に編集。

注 10）ヘルシンキ都市計画局が局内資料として作成した既存文化的環境－詳 細計画図保存規定策定の原則, 3.2.1. 建物にかかる保存規定, 保存理由, pp21〜22 から著者が抜粋・翻訳

注 11）ヘルシンキ都市計画局詳細計画課では 1987 年に商業中心地区計画と 開発の原則/Liikekeskustan kaavoitus-ja kehittämisperiaatteet および 地下空間とその活用 Maanalaiset tilavaraukset ja toimintasuositykset/ (ヘルシンキ都市計画局地区詳細計画課 1987 年 8 月 24 日) を作成。マッカラタロの詳細計画変更解説書 $\mathrm{p} 2 、 \mathrm{p} 16$ ではマッカラタロ 3 階の駐車場は撤去し、マッカラタロ扶持義務 201 台分は地下の一般駐車場 に移寸と説明。

注 12）マッカラタロ都市景観精查/ Makkaratalon kaupunkikuvallinen tarkastelu）を作成した。（2004 年 Kari Jarvinen ja Merja Nieminen Arkkitehdit SAFA に依頼作成)
注 13）都市計画課の作成する土地利用計画図を審議する委員会。ヘルシンキ 都市計画委員会は 9 名で構成されすべて直接選挙によって選出された地方 議員である。委員の構成は各政党の議員数の比例によって選出される。委 員会で審議された計画は市議会にあげられ議会承認の運びとなる。

注 14）「マッカラタロ、エルメス敷地およびケスクスカトゥ通り北端部地区 詳細計画変更」議事録 2005 年 3 月 10 日/10.3. 2005/MAKKARATAL0 JA HERMEKSEN TONTTIEN SEKA KESKUSKADUN POHJOISEN ASEMAKAAVAN MUUTOS (NR011390)

議事録には当該建物の保存要件について、2001 年 2月 15-17 日 ICOMOS 会 議（ヘルシンキ開催）で近代建築の保存として広範に議論を喚起した事例 としてマッカラタロが取り上げられ、会議では 3 通りの見解が示されたと 記載されている。「1バルコニーおよび車両用斜路は都市景観として好まし くないとし解体撤去する。2 アメリカ的車社会（設計者 Revel1 は近未来の 都市イメージとして想定した）のシンボルとしてバルコニーと車両用斜路 を保存する。3 問題に対する市民的議論と歩行者の環境の改善を前提とし た改築を許可する。」

注 15）考古局声明 2005 年 5 月 3 日、

ヘルシンキ市立美術館声明 2005 年 4 月 28 日

注 16)「マッカラタロ、エルメス敷地およびケスクスカトウ通り北端部地区 詳細計画変更」議事録 2005 年 6 月 16 日 p 14 a

注 17）都心部建物保存台帳/Kantakaupungin rakennussuo jeluinventointi/ City center building preservation inventory よりサルミサーレンタロ の建築概要から（著者抜粋、翻訳）

注 18）参考文献 24)から「ヴィルヨ・レヴェルは 1959-67 年ヘルシンキに後 年ソーセージビルとして有名となる商業ビルを設計した。その圧倒的な存 在感は、その賛否について今でも熱い議論が交わされる。」（著者抜粋要 約)

注 19）「土地利用と建物の法律」第 62 条および第 63 条により地区詳細計画 作成の手続きが規定されている。ヘルシンキ都市計画課では地区詳細計画 変更申請がなされた後、初動として計画によって影響を受ける関係者・団 体を一堂に会し、計画の目的や対象建物の評価についての会議をもつ。会 議は OAS 会議(参加と評価の組織/0sallistumis-ja ArviointiSuunnitelma) と呼ばれる。この会議の後、都市計画課による地区詳細計画作成業務は下 図のように各段階を経て最終的に議会承認を得て施行となる。

\section{地区詳細計画作成作業プロセス/kaavan kulku * 都市計画課提供資料よ} り著者編集（事例 1、2 のプロセスおよび経過年を記入）

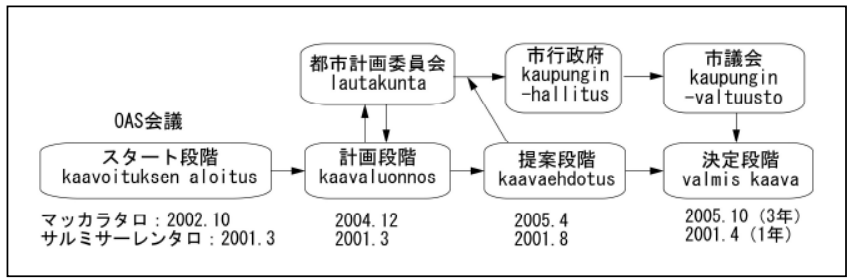

注 20)都市計画課が地区計画変更を検討する際に既存建物保存の重要性を鑑 み作成する建築調査報告書/Selvitys。サルミサーレンタロでは都市計画局 がリヴァディ建築事務所/Arkkitehtitoimisto Livady に外注委託し作成し た。報告書は全 194 頁で構成されている。2001 年 2 月 22 日作成。

注 21）KTY/s は当該敷地の保存規定を表す。KTY は事務所、環境に害を及ぼ さない工業や倉庫等の用途に供する地域を表す。/ $\mathrm{s}$ は当該敷地環境を保護 することを示す。

注 22) Arkkitehti 6/2005 p30 「高層棟の空は水平に、低層棟の空は垂直に というVähäkallioの原則に沿って新規空は水平に、そしてさらに原則を強 調するように水平のルーバーを設置した」トゥオモ シートネン/Tuomo Siitonen（著者抜粋翻訳）

注 23）地区詳細計画変更では、保存規定の他に屋根の許容最高高さ（高層棟 は+40.53）および屋上に室、機器を置く場合にはパラペットから $3 \mathrm{~m}$ 以上 の後退距離が定められている。 


\title{
OPERATIVE CASE STUDY OF THE PRESERVATION TECHNIQUE ACCORDING TO THE PART OF THE MODERN ARCHITECTURE CONVERSION IN THE HELSINKI INNER CITY
}

\author{
Masami TANAKA*
}

* Architect, Masami Tanaka Architect and Associates Inc.

This report is a study on use of the preservation technique according to the part of the modern architecture conversion. For this study purpose I investigated the conversion example of the inner city of Helsinki that had the system which prescribed the part to preserve of the existing building legally and considered it how the preservation according to the part of the existing building acted for the creation of the conversion building. I got the knowledge of following four items as findings.

1. The Helsinki City Planning Department prescribes a preservation part and the purpose of the existing building by a local detailed plan. And it was confirmed that the drafting work of the local detailed plan applied the preservation technique according to the part from an investigation of example 1 and example 2. Preservation contents are shown in the preservation regulation by a preservation level and preservation requirements. The preservation level is usually distributed between three phases of sr-1、sr-2、sr-3 depending on importance and is managed.

2. The building of example 1 is located in the center of Helsinki. The Helsinki City Planning Department spent much time to decide the preservation regulation of this building and examined it carefully among other things. In this period the City Planning Department consulted preservation contents in a drafting stage at Helsinki City Museum and the National Board of Antiquities several times and got statements. The decided preservation regulation bears fruit in a facade design of the new conversion architecture, and it is with the example that a preservation regulation was shown to have serious influence in a design of the conversion architecture. Example 1 asked about a meaning of the preservation fundamentally in conversion architecture and, in this respect, showed the new possibility of the architecture value to be enabled only with the conversion building which we could not bring about with new building.

3 Example 2 has an outstanding character for a use change in a conversion plan. The existing building that has the value as the modern architecture inheritance was assorted according to a part while fixing its eyes on a new use, and a preservation level was decided to each part. The sr-1 part was restored to the original state as historical materials and was saved. A great deal of remodeling was carried out for space function to be required by a new use while adhering to the pillar which incarnated the characteristic space constitution of the existing building as a preservation factor in the sr-2 part. While each different intention of preservation and the improvement was reflected definitely, the new space that two purposes fused, and took in historic temporal axes was built, and example 2 showed new possibility of the architecture creation that we could make by a conversion building.

4. The Helsinki City Planning Department updates a local detailed plan to the projection of the conversion plan. In addition, the update work of the local detailed plan started with OAS meeting, and it was confirmed to apply the preservation technique according to the part while fixing its eyes on a reevaluation and the conversion purpose of the existing building as a sheet of plastic from an initial stage in consideration for a local detailed plan. This operation procedure brings a preservation intention and a conversion purpose close mutually. And bring flexibility and diversity in a preservation regulation and widen the originality of the conversion building new possibility. 